\title{
Correction to: Polybrominated diphenyl ethers and its methoxylated analogues in biota and sediment samples from two freshwater lakes in Yangtze River delta
}

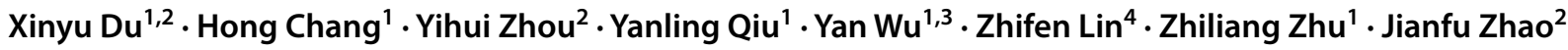

Published online: 2 August 2019

(c) The Author(s) 2019

\section{Correction to: Environ Earth Sci (2017) 76:171 \\ https://doi.org/10.1007/s12665-017-6499-7}

The article "Polybrominated diphenyl ethers and its methoxylated analogues in biota and sediment samples from two freshwater lakes in Yangtze River delta, written by Xinyu Du, Hong Chang, Yihui Zhou, Yanling Qiu, Yan Wu, Zhifen Lin, Zhiliang Zhu and Jianfu Zhao, was originally published electronically on the publisher's internet portal (currently SpringerLink) on 18 February 2017 without open access. With the author(s)' decision to opt for Open Choice the copyright of the article changed on June 21, 2019 to () The Author(s) 2019 and the article is forthwith distributed under the terms of the Creative Commons Attribution 4.0 International License (http://creativecommons.org/licenses/ by/4.0/), which permits unrestricted use, distribution, and reproduction in any medium, provided you give appropriate credit to the original author(s) and the source, provide a link to the Creative Commons license, and indicate if changes were made.

The original article has been corrected.

The original article can be found online at https://doi.org/10.1007/ s12665-017-6499-7.

Yanling Qiu

ylqiu@tongji.edu.cn

1 Key Laboratory of Yangtze River Water Environment (Ministry of Education), College of Environmental Science, and Engineering, Tongji University, Shanghai 200092, China

2 State Key Laboratory of Pollution Control and Resource Reuse, College of Environmental Science and Engineering, Tongji University, Shanghai 200092, China

3 Department of Zoology, Southern Illinois University Carbondale, Carbondale, IL 62901, USA

4 Shanghai Key Lab of Chemical Assessment and Sustainability, College of Environmental Science and Engineering, Tongji University, Shanghai 200092, China
Open Access This article is distributed under the terms of the Creative Commons Attribution 4.0 International License (http://creativeco mmons.org/licenses/by/4.0/), which permits unrestricted use, distribution, and reproduction in any medium, provided you give appropriate credit to the original author(s) and the source, provide a link to the Creative Commons license, and indicate if changes were made.

Publisher's Note Springer Nature remains neutral with regard to jurisdictional claims in published maps and institutional affiliations. 